OPEN ACCESS
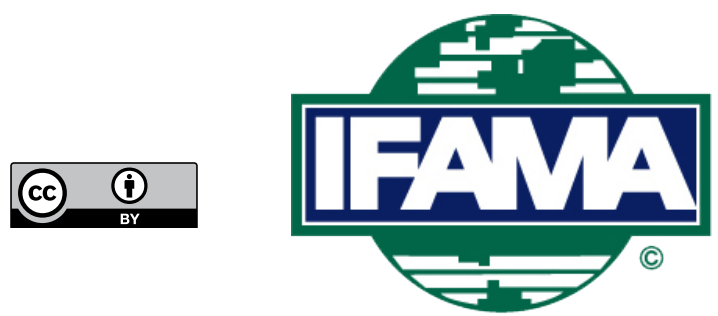

International Food and Agribusiness Management Review

Volume 25, Issue 3, 2022; DOI: 10.22434/IFAMR2021.0103

Received: 12 August 2021 / Accepted: 24 November 2021

\title{
Finding the right price: supply chain contracts as a tool to guarantee sustainable economic viability of organic farms
}

RESEARCH ARTICLE

\author{
Elena Viganò ${ }^{(a)}$, Martina Maccaroni ${ }^{\mathrm{b}}$ and Selene Righi ${ }^{\mathrm{c}}$ \\ ${ }^{a}$ Full Professor, ${ }^{b} \mathrm{Dr},{ }^{c} \mathrm{PhD}$ student, Department of Economics, Society, Politics, \\ University of Urbino Carlo Bo, Via Saffi, 261029 Urbino (PU), Italy
}

\begin{abstract}
The aim of this study is to analyse the volatility of agricultural commodity prices and assess the effectiveness of supply chain contracts as possible tools to prevent it. The study refers to the cereal sector, which is of vital importance for the agri-food system of the Mediterranean area. Since Italy is the world's largest producer of durum wheat semolina, the proper functioning of the Italian durum wheat supply chain is central to this investigation. The study was conducted following two different paths of analysis: (1) the calculation of volatility indices using annual and monthly data of durum wheat prices, both organic and industrial, observed in the Bologna Commodity Exchange (AGER); (2) the analysis of two organic durum wheat supply chain contracts, defined by a cooperative involving hundreds of Italian farms mainly from the Marche region and by an agricultural consortium operating in the Adriatic regions. Despite the limited number of cases examined, the present study shows how supply chain contracts can be valid tools for building stable relationships between the various players, from production to processing and distribution, guaranteeing farms fairer and more remunerative raw material purchase prices and higher quality standards.
\end{abstract}

Keywords: commodity price volatility, durum wheat, supply chain contracts, organic farming, innovation JEL code: D22, L14, Q13

\footnotetext{
${ }^{\circledR}$ Corresponding author: elena.vigano@uniurb.it
} 


\section{Introduction}

The traditional agri-food system based on an industrial and intensive productive model is undoubtedly unsustainable in environmental, social and economic terms (SAPEA, 2020). However, the switching towards coherent models based on ecological transition and climate neutrality is strictly connected to the achievement of an adequate profitability for the agricultural firms (FAO, 2018).

As a result of the conjoint effect of external and internal drivers, crop yields and prices are strongly characterised by sharp fluctuations, negatively affecting farmers' planning decisions (Brümmer et al., 2015; Morales, 2017; Tadesse et al., 2014). Moreover, a further element of instability is represented by an unbalanced bargaining power that favours processing and distribution industries. This results in an unfair price paid to farmers, not in line with the appropriate level of remuneration, and this applies also to more sustainable productions, like organic farming (European Commission, 2020a).

The purpose of this study is to analyse price volatility of agricultural commodities to assess the effectiveness of supply chain contracts in building stable relationships between producers, processing industries and distributors, with the aim of guaranteeing both fair purchase prices paid to producers (Bailey et al., 2021; Jang and Olson, 2010; Jarzebowski et al., 2013) and high qualitative standards (Carillo, 2016).

The analysis refers to the cereal sector, in particular durum wheat, which is the basis of many national economies located in the Mediterranean area. The Italian market was considered for the price analysis, while for supply chain contracts, we focused especially on the Marche region, which is one of the most important Italian regions in terms of areas dedicated to organic production, with an incidence in 2020 of 23.8\% (Gerini, 2021). For durum wheat, in particular, Marche is the first region in the Centre-North in terms of the incidence of the area dedicated to the cultivation of organic durum wheat on the total organic area (6.4\%) and the fifth in Italy after Basilicata (22.8\%), Molise (13.5\%), Puglia (13.5\%) and Sicily (9.6\%) (www.sinab.it/bio-statistiche).

To define a theoretical framework, Section 1 reports the overall review of the available literature related to price volatility and asymmetric price distribution. In Section 2, the materials and methods used to carry out the empirical study are described, following two different paths of analysis, one on the volatility of agricultural prices and the other on supply chain contracts, researching and analysing both the Italian legislative framework and the literature which, however, turned out to be limited. This may be considered as a further reason to carry out the study. Section 3 presents the results of the analysis, by first computing a volatility index, both global and intra-and inter-annual, according to annual and monthly price dynamics of durum wheat, both organic and conventional observed in the Commodity exchange of Bologna, which is an important reference point for Italian cereal firms, in particular for organic crops. This analysis is essential in order to study supply chain contracts as innovative tools to support the transition towards sustainable production models. Thanks to willing privileged witnesses, it was possible to further investigate two supply chain contracts which aimed to strengthen the relationship of horizontal and vertical integration between different actors and improve their production and sales performance. Some concluding remarks are reported in Section 4.

\section{Theoretical framework}

\subsection{The economic (un) sustainability of agri-food supply chain}

The European food system has reached high levels of food safety by offering a wide range of different products to consumers, despite being still characterised by a strong unsustainability in environmental, social and economic terms (European Commission, 2020c). The industrial productive model applied to agriculture and first proposed within the so-called green revolution has led to a strong increase in productivity of land and labour, accompanied, however, by a multitude of negative externalities in terms of water and soil pollution, biodiversity loss and ecosystem destruction, greenhouse gas emissions as well as compromising 
the health of both producers and consumers (European Court of Auditors, 2020; Mostafalou and Abdollahi, 2017). These negative impacts are directly linked to the massive use of fossil fuels and synthetic chemical products, such as fertilizers and pesticides. Furthermore, the simplification of the production system, the reshaping of land use in the arable area around the 2000s induced by common agricultural policy (CAP) reform, together with the reorganization of the supply chain at a global scale, have also compromised the possibility of guaranteeing adequate profitability for many European farms working in rural areas (De Olde et al., 2016; FAO, 2018).

The new European Green Deal, and in particular, the Farm to Fork Strategy (European Commission, 2020a) are one of those fundamental steps that must be taken to develop a sustainable, fair, healthy and environmentallyfriendly food system (European Commission, 2020c). By implementing this strategy, the European Union is aiming to drastically reduce pesticide and fertilizer employment and exploitation and to convert at least $25 \%$ of European agricultural land into organic farming, which now represents the main alternative to the industrial and intensive production model, with several positive implications in terms of sustainable management of common goods (European Commission, 2020b; Sturla et al., 2019). This productive model is based on principles of health, ecology, equity and recovery (IFOAM, 2008), which are strictly ruled and certified at global level. Its main features are the total abandonment of pesticide and fertilizer use as well as GMO, and the strong reduction of external productive inputs, which help easing harvest and breeding conditions. Indeed, a great part of what cultures and breeding need, may be found in the responsible and sensible use of natural resources locally sourced, together with the exaltation of natural cycles and positive interactions within the different living organisms, which coexist in the same agroecosystems, human beings included (Bàrberi, 2015; Rodale Institute, 2015).

Therefore, organic farming is a production model capable of containing the negative environmental externalities related to agricultural activity as much as possible as demonstrated by a large body of scientific literature (by way of example only, see Skinner et al., 2019; Tuck et al., 2014). However, the spread or strengthening of this production model requires the achievement of adequate levels of profitability for companies, regardless of the funding provided by the CAP or initiatives that could be activated by local authorities, for example through public procurement (Blasi et al., 2016). This is particularly true at a time when the indications of the European Union could facilitate the entry of large companies that are extremely competitive in terms of product quality linked to the characteristics (environmental, social and cultural) of specific territorial contexts (Antonelli and Viganò, 2018).

A central element affecting the economic viability of companies is price, whose trends are currently volatile and have a downward trend due to the increasing competition driven by a strong development in intensive production models and aggressive marketing strategies implemented by international traders. Commodity prices are not only affected by financial speculation, but also by the reorganization of the relationship between the different actors working in the agricultural supply chain. Indeed, farms suffer the negative effects due to a strong inequality of bargaining power in favour of bigger transportation and distribution industries. This results in an unprofitable price paid to producers, who are actually unable to compensate for their productive inputs and ensure themselves an adequate profitability (Mariani and Viganò, 2013).

Different studies (Brümmer et al., 2015; Tadesse et al., 2014) agree that only one driver is unlikely to be the trigger behind price instability and volatility, but the conjoint effect of different factors can probably explain both. Influential factors can be classified into structural and conjectural. Structural factors directly affect price volatility and are responsible for gradual changes defining a specific trend over an extended timeframe. Specifically, structural causes can be divided into supply-side factors that, have a direct effect on production levels and, by others that affect the demand side (Brümmer et al., 2015; Götz et al., 2015; Haile et al., 2014; Ott, 2014; Tadesse et al., 2014). Conjectural factors are unexpected sudden events determining pressure on prices and are directly related to price dynamics. Among these factors, public administration policies can directly impact global production and consumption, stock levels and trading volumes (Rude 
and An, 2015), whereas price dynamics in oil and energy markets influence input prices (Bobenrieth et al., 2013; Brümmer et al., 2015; Ohashi and Okimoto, 2016; Tadesse et al., 2014).

Understanding which the factors are responsible for price volatility, both in the short and the medium to long term, is a first relevant step to prevent possible negative effects threatening agricultural crops. Together with price volatility, the asymmetric distribution of prices along the supply chain is another key factor in economic uncertainty. This can be explained as a different change of price in terms of pace and size paid to producers when the retail price tends to increase or decrease (Cacchiarelli and Sorrentino, 2018). It mainly consists in an unfair distribution of the added value among producers, food processing companies, wholesalers and retailers. When the purchase price of the commodity drops, as a result of a strong bargaining power, food processing industries assume opportunistic behaviour: this means that the retail price remains the same, whilst the production price will get lower and lower. Having a supply chain that works efficiently and effectively is a fundamental step to increasing competitiveness and profitability (European Commission, 2020a). Retail prices may be defined as sticky, since they are not properly affected when supply levels change. Contrarily, an increase in production leads to an excess in supply that affects pricing mechanisms and has negative repercussions on commodity purchase prices. In this context, consumers cannot really take advantage of falling prices at the origin by obtaining lower prices (Sexton and Lavoie, 2001).

Moreover, a particular attention should be paid to asymmetric adjustments of price. The intensity of price change upstream is different among the different actors participating in the supply chain due to the influence exerted by different factors, such as the presence of structural production costs, the competitiveness of market structure, the possible state intervention and the common belief that a reduction in upstream prices would be only temporary (Ricci et al., 2019). In order to understand this point better, it is important to remember that the food supply chain is characterised by a great diversity of market structures, which have different degrees of vertical and/or horizontal integration and a wide range of economic players, from independent medium and small-sized enterprises to multinational corporations. Non-competitive market structure and the exertion of a strong market influence are often perceived as the potential main drivers causing an imperfect price transmission. In particular, there is a lack of market balance when larger businesses can impose particular contractual terms that can reduce or delay the transmission when prices change (European Commission, 2009).

\subsection{Supply chain contracts}

In order to evaluate the effectiveness of supply chain contracts, we started by researching and analysing both the relevant literature and the Italian legislative framework. Supply chain contract is a contractual tool established by Law no. 289 of 27 December 2002 with the aim of supporting the integration of the supply chain and enhancing the overall value of agri-food products taking into account both farmers' and consumers' interests. According to Law no. 102 of 27 May 2005 in Article 9, the agreement can define:

- actions to improve the knowledge and transparency of production and market;

- actions to coordinate better product launching;

- model contracts compliant with European law to agree terms regarding harvest, breeding and supply;

- methods to promote and protect designation of origin, indication of origin and quality label;

- criteria to strengthen the bond with local productions and the territory of origin.

Contracts agreed in the supply chain are formal agreements where the parties involved shared and subscribed objectives, operative strategies, obligations and commitments that must be fulfilled, specific roles and responsibilities. These agreements represent an organizational innovation along agri-food supply chain and allow the different producers involved to coordinate better with each other and increase their overall competitiveness (Filippi et al., 2021). Contracts between producers involve both long-term integration agreements between the various players for investment and joint research, and cultivation through agreements focused on the commercial transaction between the agricultural and transformation phases. 
Different model contracts are now spreading in Italy that differ from each other in the pricing method used (Table 1). Generally, regardless of the specific contractual format, the premium price paid depending on the grain quality is welcomed by the agricultural actors. However, the economic bonus must be really stimulating for farmers to reach both a higher price paid (Jang and Olson, 2010; Jarzebowski et al., 2013) and higher quality (Carillo, 2016; Zanni and Viaggi, 2012).

\section{Materials and methods}

\subsection{Analysis of price volatility}

In order to quantify the impact of price volatility, we analysed agricultural commodity prices. Price volatility is an indicator of how much and how fast the price of the commodity changes over time. It is measured in terms of price dispersion around a central trend (Ott, 2014; Santeramo and Lamonaca, 2019; Tadesse et al., 2014). As suggested by Santeramo and Lamonaca (2019), the indicator $\left(\sigma_{m}^{n y, i}\right)$ measures global volatility as the standard deviation of logarithmic changes in monthly price of commodity $i$ from a central trend, computed using a moving average on $12 \times n$ months with $n$ indicating the number of years concerned:

$\sigma_{m}^{n y, i}=\sqrt{\frac{1}{12 n-2} \sum_{m=2}^{12 n}\left(\ln \left(\frac{P^{y, i}{ }_{m}^{y, i}}{m-1}\right)-\mu_{y}^{n y, i}\right)^{2}}$

In order to have a more accurate analysis, it is convenient to differentiate intra-annual volatility from interannual volatility.

Intra-annual volatility, defined as price dispersion within a crop year, affects short-term decisions, such as plating. As proposed by Ott (2014), intra-annual volatility $\left(\sigma_{m}^{y, i}\right)$ is measured as the standard deviation of logarithmic changes in monthly prices of commodity $i$ within a crop year from annual average price:

$\sigma_{m}^{y, i}=\sqrt{\frac{1}{10} \sum_{m=2}^{12}\left(\ln \left(\frac{P^{y, i}{ }_{m}}{P^{y, i}{ }_{m-1}}\right)-\mu_{y}^{y, i}\right)^{2}}$

where:

$P_{m}^{y, i}=$ monthly price $m$ of year $y$

$\mu_{y}^{y, i}=\frac{1}{11} \ln \left(\frac{P_{12}^{y, i}}{P_{1}^{y, i}}\right)$

Table 1. Supply chain model contracts.

\begin{tabular}{ll}
\hline Model contract & Pricing method \\
\hline Mixed closed-opened price & - For one share of the harvest, price is defined as 'closed' in pre-seeding, considering \\
& both production and stock costs differentiated by area. \\
& - For the remaining share, price is defined as 'opened' according to the prices \\
& occurring on the reference stock exchange. \\
& - A premium price depending on quality standards may be added to the latter. \\
& - Price is prefixed 100\%. \\
Closed & Premium price for determined quality features is included. \\
Semi-closed min-max & A range between a maximum and minimum price is defined. \\
& - If price on the stock exchange is below the lower limit, minimum price will be paid. \\
& - If the price is over the upper limit, maximum price will be paid.
\end{tabular}


The higher intra-annual volatility $\left(\sigma_{y}\right)$ is the harder it is to choose the most convenient crop to harvest.

In line with Ott (2014) and Santeramo and Lamonaca (2019), inter-annual volatility $\left(\sigma_{y}^{y, i}\right),{ }^{1}$ defined as price dispersion among crop years over a defined period of time, is measured as the standard deviation of annual price of the commodity from a moving average computed over the 9-year period considered.

$\sigma_{y}^{y, i}=\sqrt{\left(\Delta P_{y}^{y, i}-\Delta_{9} P_{y}^{y, i}\right)^{2}}$

where:

$\Delta P_{y}^{y, i}=\ln \left(\frac{P^{y, i} y}{P^{y, i} y-1}\right)=$ annual average price

$\Delta_{9} P_{y}^{y, i}=\frac{1}{9} \ln \left(\frac{P^{y, i} P_{y+2}^{y, i}}{y-2}\right)=$ moving average on 9 years

This measure assumes that agents are able to predict the long-term price trend but not the deviation around this moving average. This therefore indicates the risk incurred by farmers in making long-term decisions. However, since revenues then depend on price levels, large deviations around the expected trend price imply greater uncertainty.

Agricultural commodity prices are related to the Italian context. In particular, we have chosen to focus on durum wheat due to its vital importance for the Italian agrifood system. ${ }^{2}$ As a dataset, we refer to annual and monthly average prices of durum wheat, both conventional and organic, defined by the Commodity exchange of Bologna from 2012-2020. The price lists made by AGER (Associazione Granaria Emiliana Romagnola), according to trends occurring in the Commodity exchange of Bologna, are the benchmark for the Italian actors operating in agriculture, and in particular, in grain markets. In addition, there is a specific part dedicated to organic products. The prices considered are those of national durum wheat and in the case of conventional wheat we consider the one harvested in central Italy which is defined as 'Durum wheatbuono mercantile-rinfusa arrive' while in the case of organic wheat it is 'Durum wheat-rinfusa arrive' both 'Franco-arrivo Bologna'. 3

\subsection{Analysis of supply chain contracts}

The aim of this study is to understand and assess the effectiveness of these types of contracts, since they may be seen as an alternative method to rebalance the relationships along the supply chain and mitigate the negative effects related to price volatility. In order to achieve the study's objective, our research design implied an inductive exploration of the contemporary empirical phenomenon aimed at revealing what type of supply chain contracts are adopted by agri-food enterprises. Based on the inductive and exploratory nature of our study (Yin, 2018), the analysis was then expanded through qualitative research, adopting an exploratory multiple case study approach, with the principal aim of developing new and valid theoretical and operational insights.

Notably, the case study has been selected for the significance of the phenomenon because it introduces local context and situational constraints. However, with an 'intrinsic' case study we cannot generalise the outcome or attempt to build theories, while the multiple case study approach allows for more general conclusions

\footnotetext{
${ }^{1}$ Equation 2 of Santeramo and Lamonaca (2019) is a reformulation of Ott (2014) to improve coherence formulations used in the analysis.

2 In a context of a fluctuating trend of the sector, durum wheat has, in 2019, an incidence equal to $35.2 \%$ of the value of Italian cereal production, contributing to feed above all the pasta chain, one of the most important for the 'Made in Italy', with a value equal to 5.9\% of total exports-2019 (CREA, 2020). Even in the organic sector, durum wheat is one of the most significant crops (ISMEA, 2020).

${ }^{3}$ Conventional durum wheats available in the market are divided into three categories: 'fino', 'buono mercantile' and 'mercantile'. These three categories differ in protein level, moisture level and hectolitre weight. 'Franco-arrivo Bologna' prices are in $€ / t$ for prompt delivery to an agreed place. They identify the prices of the product purchased on arrival at the storage point (of the trader, processor, other producer, etc.), i.e. with the transport costs, and the risks this entails, borne by the farmer. These prices are usually higher, compared to 'Franco-partenza' prices, because they actually contain an additional cost to normal agricultural production (the cost of transportation).
} 
and more direct comparisons of similarities and differences in implementation practices within a specific context of analysis (Silverman, 2000; Stake, 2013; Yin, 2018). Information from multiple sources provides a more complete and comprehensive understanding of the topic under study, so that further elaboration and hypotheses can be created, making an 'analytical generalisation', completing quantitative studies that address the topic of market instability through econometric analyses that instead aim for a 'statistical generalisation' (Yin, 2018). We used the multiple case study method with a purposeful sampling technique for selecting information-rich cases (Patton, 2001) by deciding to select enterprises/decision makers that adopt a supply chain contracts for durum wheat/pasta, willing to provide all the elements that characterise the supply chain contracts undersigned, which are usually considered sensitive information and not easy to find.

Regarding data analysis, we adopted the three-step approach of Miles and Huberman (1994), which consists of data reduction, data display, and verification. Further data have also been collected from additional sources - such as the firms' websites, direct observations, annual reports and other files - for data triangulation (Baxter and Jack, 2008). At first, we identified the main actors operating in the pasta supply chain in the Marche Region to be used as key informants to interview them. Key informant methodology is a technique well described by Tremblay (1955) as pre-eminently suited to the types of qualitative and descriptive data that are difficult or time-consuming to discover through structured data collection techniques, such as questionnaire surveys.' In our study this allowed us to exploit the most experienced sources of information. Its main advantage is that it allows us to collect good quality information, in a relatively short period of time and with a small sample of respondents who are considered 'experts'. The most significant disadvantage of this technique is that it is not representative of the thinking of the majority of the population (Marshall, 1996).

In particular, among the various stakeholders, after explaining in detail the objective of the research and requesting their willingness to participate in the study, fifteen key informants were available: two presidents of agricultural cooperative/consortium, four organic entrepreneurs and farmers, one representative of the main trade unions and one of Confcooperative Marche, five agronomists and two expert consultants in the agri-food sector. The interviews were conducted between December 2020 and January 2021 and the interview guide was created based on the literature previously discussed. The questions revolved around different topics, such as the personal characteristics of the interviewees and the company or organization they belong to, the characteristics of the supply chain contracts such as strengths and weaknesses detected, the main objectives and tools, the pricing method used and the consignment and payment terms. The text of the interview outlines can be found in Appendixes 1 and 2 of the Supplementary Material.

It was possible to construct a SWOT analysis that allows us to standardise the collection of information obtained from the interviews with these key informants that shows the advantages and disadvantages of supply chain contracts and the strengths and weaknesses of these tools (Tamayo-Orbegozo et al., 2017). Through a discussion of the preliminary outcomes resulting from our interviews with the main actors we had identified, we subsequently verified the accuracy of our interpretation with other scholars, ${ }^{4}$ including from universities, who are experts in the field. In particular, along with the interviews, to investigate further, the President of an organic cooperative and the President of an agricultural consortium gave us access to their supply chain contracts so we could analyse and compare them. Considering the firms' desire to remain anonymous, their names and the interviewees' names were not disclosed, and fictitious denominations have been used, namely, Farm 1, and Farm 2.

\footnotetext{
${ }^{4}$ In particular, several discussions were carried out with two researchers from the Council for Agricultural Research and Economics - Research Centre for Agricultural Policies and Bioeconomy and with six university lecturers, experts in International marketing and International Business Management, Economy of the Environment and the Territory and Economy of Innovation, Economy and Management of enterprises, Total Quality Management (from the University of Urbino Carlo Bo), in Value Chain Management (from the Alma Mater, University of Bologna) and Computer Vision and Informatics (from Polytechnic University of Marche).
} 


\section{Analysis of results}

\subsection{Price volatility of organic and conventional durum wheat}

The analysis starts from analysing global price volatility of organic and conventional durum wheat, that catch both intra- and inter-annual volatility. The considered time frame is however limited, since other studies have focused their price volatility analysis over a wider time scale and using global prices (Ott, 2014; Santeramo and Lamonaca, 2019; Tadesse et al., 2014). By computed the indicator $\left(\sigma_{m}^{n y, i}\right)$ proposed by Santeramo and Lamonaca (2019) for the considered time frame, the global price volatility of organic durum wheat is lower with a value of 0.0343 compared to the conventional one of 0.0489 . However, if we distinguish between intraand inter-annual volatility, we can see the trends over the period in more detail and also see mixed results.

Considering intra-annual volatility (Figure 1A), the price of conventional durum wheat has been significantly more volatile but almost always with higher values. For inter-annual volatility (Figure 1B), the trend is similar for both production methods although it is higher in the period considered. Prices tend to differ, probably influenced by changes in supply levels. This means that medium and long-term decisions tend to be riskier due to the longer period which makes reliable decisions impossible. Based on these results, it can be said that, overall, conventional durum wheat has an inherent risk that is not compensated by higher purchase prices compared to organic durum wheat. In any case, this does not mean that organic crops suffer from less risk but can be interpreted as another reason to switch to more sustainable production models. As can be seen from Figure 2, prices for organic production have always been higher, although with a similar trend to conventional production.

Focusing on the last months, it can be seen that the prices of organic and conventional durum wheat are becoming increasingly closer (Figure 3), and this could be a problem as farmers could decide to abandon the organic system as they consider it not adequately profitable. The instability that characterises price levels depends on multiple factors including the dynamics of international markets. In particular, the Italian durum wheat market is characterised by a high domestic demand that is not matched by an equal increase
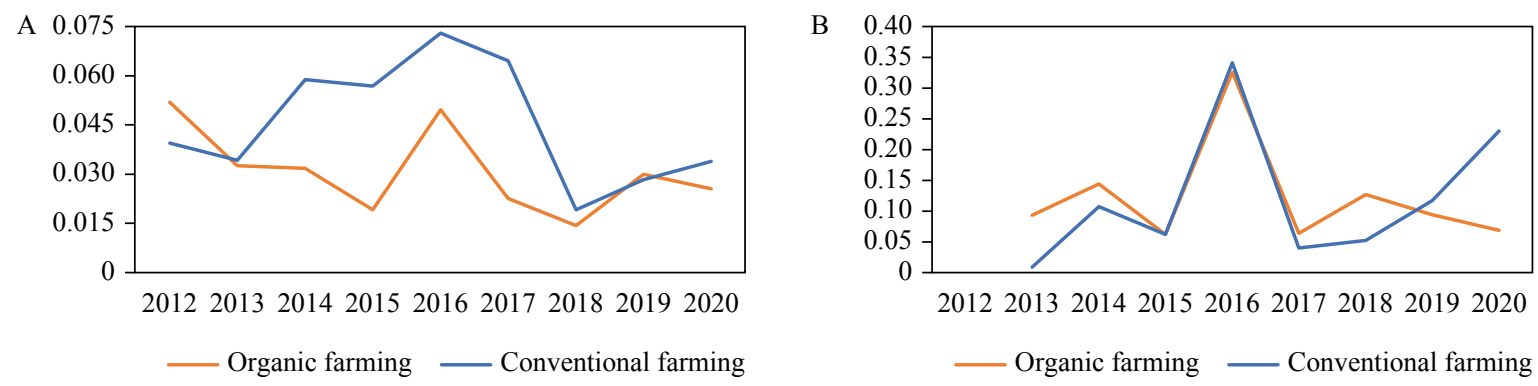

Figure 1. Intra-annual (A) and inter-annual (B) volatility of conventional and organic durum wheat prices (2012-2020).

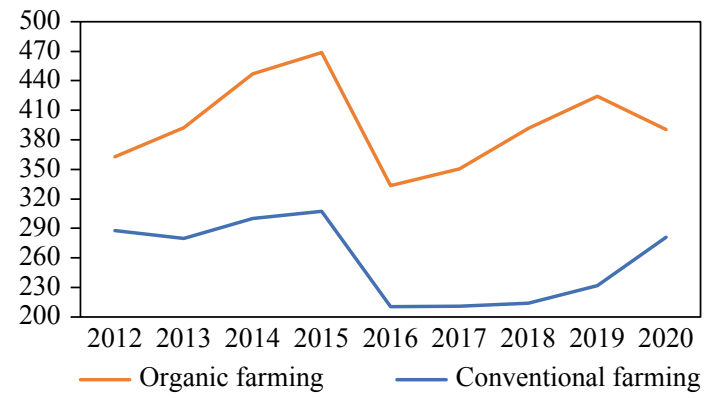

Figure 2. Average annual prices (2012-2020; euro/t). 


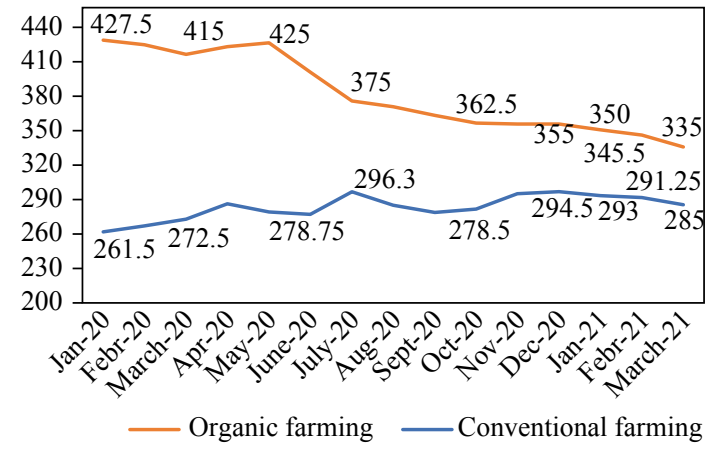

Figure 3. Monthly prices (from Jan 2020 to March 2021; euro/t).

in supply, so imports must be used to increase market and price instability. In Italy, the volatility of organic products prices could also be explained by the concentration of the market. In fact, there are a few large and powerful mills, which define prices in their favour according to supply and demand, thereby influencing overall market prices.

\subsection{Analysis of supply chain contracts}

The analysis of price volatility is essential to the study of supply chain contracts, carried out through interviews with privileged witnesses operating in the cereal sector, in order to identify their efficiency and effectiveness in guaranteeing fair profitability to farmers. Supply chain contracts are finding it easier to spread along the pasta supply chain (Solazzo et al., 2015; Zanni and Viaggi, 2012) for the durum wheat production, which represents its key element (Carillo, 2016; Jang and Olson, 2010).

\section{- The supply chain contracts: a SWOT analysis}

Thanks to the collaboration of various privileged witnesses, supply chain contracts were examined and discussed, allowing for a SWOT analysis to be created that attempts to summarise the advantages but also the obstacles in the adoption of these contracts (Table 2).

Table 2. SWOT matrix on supply chain contracts.

\begin{tabular}{|c|c|}
\hline Strengths & Weaknesses \\
\hline $\begin{array}{l}\text { - Predetermined price. } \\
\text { - Guaranteed minimum price. } \\
\text { - Premium for quality features. } \\
\text { - Support from expert agronomists. } \\
\text { - Facilitated prices for the purchase of seeds, } \\
\text { inputs and insurance contracts. } \\
\text { - Withdrawal of fodder crops/oily grains. }\end{array}$ & $\begin{array}{l}\text { - Limitation of trade. } \\
\text { - Observance of strict cultivation regulations. } \\
\text { - Increase in production costs for higher quality } \\
\text { standards or need for investment. }\end{array}$ \\
\hline Opportunities & Threats \\
\hline $\begin{array}{l}\text { - Increased profitability. } \\
\text { - Mitigation of the risk of price volatility. } \\
\text { - Increased bargaining power. } \\
\text { - Better distribution of added value along the supply chain. } \\
\text { - Preventive seeding planning with guaranteed purchase } \\
\text { of the product. } \\
\text { - Increase in the overall quality of supply. }\end{array}$ & $\begin{array}{l}\text { - Volatility of agricultural prices. } \\
\text { - Low bargaining power. } \\
\text { - Increased pressure from international competition. } \\
\text { - Increased imports of organic durum wheat from } \\
\text { abroad. } \\
\text { - Extreme weather and climate conditions. }\end{array}$ \\
\hline
\end{tabular}


In general, the main benefit of the supply chain undoubtedly concerns the reduction of price uncertainty by redefining in advance clear contractual terms and this allows for an increase in the bargaining power of farms and improves the distribution of value along the supply chain, ensuring a fair price (Carillo et al., 2017). There are then other advantages, besides economic ones, that the farmer can obtain. Some of these additional services are related to the fact that they are able to plan the seeding in advance with the guarantee that what will be harvested will actually be purchased, so as to produce only the grain needed for the planned production of organic pasta. Also, it will not be necessary to go looking for a potential buyer at the time of threshing with the risk that the purchase price may drop due to fluctuations in supply and demand between the beginning and end of the crop year (Zezza, 2016). Belonging to the supply chain allows farmers to obtain facilitated insurance contracts and to always buy at a facilitated price, certified seeds and inputs.

Moreover, one of the major advantages of these tools is the possibility to count on expert agronomists who support farmers from the seeding to the harvesting phase and direct them towards the crops that can be more profitable thanks to the improvement of grain quality and production yields. However, obligating oneself through a supply chain contract can result in increased production costs due to compliance with strict production specifications. Moreover, the marketing phase is limited, as price and buyer are decided a priori, which could be a disadvantage in case market conditions are more favourable (Zanni and Viaggi, 2012).

Even if these contracts are increasingly widespread in the agricultural world, a series of obstacles do not favour their adoption by farmers and they are those of a cultural nature, due to the low level of trust that farmers show regarding the initiatives of horizontal and vertical integration. Others, derive from structural conditions, such as fragmentation, small size and lack of professionalism, and from institutional variables such as the lack of precise regulations, rather than economic constraints such as the possible increase in production costs for farmers or the need for investment.

\section{- Supply chain contract: case studies}

To investigate in more depth the real effectiveness of supply chain contracts applied in the organic agricultural sector, two case studies have been analysed. The analysed contracts pursue the objective of managing the different activities in a logic of integrated supply chain, so that it is possible to improve the distribution of the added value, increase the overall bargaining power and competitiveness of producers, also thanks to the strengthening of production services.

On the one hand, Farm 1 is an agricultural consortium in charge of grain purchase to be sold mainly to the milling industry, whereas Farm 2 is a cooperative of farmers who have come together to harvest grain to make pasta. In this latter case, the supply chain is shorter and this allows farmers to share a large part of the revenues related to the sale of pasta. Both farms are located in the Marche Region and they mainly carry out their activities in Central Italy. General elements related to the analysed supply chain contracts are collected in Table 3.

The detailed pricing method applied in the contracts is shown in Table 4. The method applied is different, but both refer to the prices listed by the Commodity exchange of Bologna. Down price is paid shortly after grain receipt, so that farms can have liquidity. Balance price is usually paid at the end of the crop year, usually in April.

According to the criteria defined by these two supply chain contracts, the balance price of organic durum wheat defined by Farm 1 might be seen as more profitable. This difference may depend on the pricing method applied, since in the first case, pricing is strictly linked to the down price. In both methods, the balance price is computed by defining the average weekly price listed by commodity exchange of Bologna. 
Table 3. Comparisons between two supply chain contracts for the provision of organic durum wheat.

\begin{tabular}{|c|c|c|}
\hline & Contract Farm 1 - Agricultural consortium & Contract Farm 2 - Cooperative of farmers \\
\hline Model contract & - Mixed closed-opened price. & - Closed. \\
\hline $\begin{array}{l}\text { Supply chain } \\
\text { composition }\end{array}$ & - Partnership with a mill. & $\begin{array}{l}\text { - Integrated supply chain composed by a mill } \\
\text { and a pasta factory of propriety. }\end{array}$ \\
\hline Objectives & $\begin{array}{l}\text { - Distinguish and enhance domestic grain } \\
\text { production and the related outputs to preserve } \\
\text { the national agricultural heritage. }\end{array}$ & $\begin{array}{l}\text { - Favour farmers' participation in integrated } \\
\text { quality systems. } \\
\text { - Re-allocate the added value of agricultural } \\
\text { commodities. }\end{array}$ \\
\hline Tools & $\begin{array}{l}\text { - Spread distinctive elements of the agricultural } \\
\text { production of Central Italy, especially, the } \\
\text { cereal stock. }\end{array}$ & $\begin{array}{l}\text { - Reduce organization and switching cost along } \\
\text { the cereal supply chain. } \\
\text { - Assign a largest share of added value to the } \\
\text { primary sector. }\end{array}$ \\
\hline $\begin{array}{l}\text { Consignment } \\
\text { terms }\end{array}$ & $\begin{array}{l}\text { - Harvest durum wheat variety allowed by } \\
\text { cultivation disciplinary. } \\
\text { - Provision of the whole production. }\end{array}$ & $\begin{array}{l}\text { - Harvest durum wheat variety allowed by } \\
\text { cultivation disciplinary. } \\
\text { - Provision of the whole production. } \\
\text { - Adopt cultivation practices functional to } \\
\text { qualitative improvement of agricultural } \\
\text { production compliant with the organic } \\
\text { harvesting method. }\end{array}$ \\
\hline Payment terms & - Not available. & $\begin{array}{l}\text { - Down payment within } 60 \text { days end of month } \\
\text { from invoice date. } \\
\text { - Balance payment within the end of April of } \\
\text { the following year after the harvest. }\end{array}$ \\
\hline $\begin{array}{l}\text { Consignment } \\
\text { limits }\end{array}$ & $\begin{array}{l}\text { - Defined qualitative standards, which if not } \\
\text { met, could limit the provision of the product. }\end{array}$ & $\begin{array}{l}\text { - Defined qualitative standards, which if not } \\
\text { met, could limit the provision of the product. }\end{array}$ \\
\hline $\begin{array}{l}\text { Prices related } \\
\text { to qualitative } \\
\text { features }\end{array}$ & $\begin{array}{l}\text { - } 2 € / \mathrm{t} \text { for each } 0.1 \% \text { between } 13.01 \text { and } \\
15.00 \% \text { of protein content in grains. } \\
\text { - Maximum price is } 40 € / \mathrm{t} \text {. } \\
\text { - If protein content is lower than } 11 \% \text {; } \\
15 € / \mathrm{t} \text { will be deducted. }\end{array}$ & - Not available. \\
\hline
\end{tabular}

In the first case, even if the down price is higher, transport and storage management costs are borne by the farms and these are directly deducted from the purchase price. Moreover, price definition is made over three different periods, where prices tend to be really different and this affects the final price. The balance price can then be increased according to particular quality features of grains. It is indeed acknowledged $2 € / t$ for each extra $0,1 \%$ protein content in grains between 13.01 and $15.00 \%$.

In the second case, the price is computed by considering only the maximum weekly prices listed by the commodity exchange of Bologna, from the first week of July to the last week of March. Moreover, it is important to highlight that storage management costs are exclusively borne by Farm 2 and transport costs are partly refunded to the associated farms. Another interesting element is some social bonus that represents a form of solidarity among farmers to allow the price to be in line with farmers' needs. Indeed, a concrete example is represented by the 2020 crop year, which was characterised by really low average prices of circa $335 € /$ ton. A social bonus approved by the Management Broad would be paid to the associated farmers, so that the price paid would be of circa $€ 370 /$ ton. In 2019 , the average maximum price was higher and the sale price was of circa $€ 410 /$ ton. 
Table 4. Pricing method.

\section{Contract Farm 1 (2017-2020)}

Down price is equal to $340 € / \mathrm{t}$

Balance price is defined as:

1. Guaranteed minimum price $\left(p_{m g N}\right)$ is $340 € /$ ton
Contract Farm 2 (2017-2021)

Down price is equal to $300 € / \mathrm{t}$

Balance price is defined as:

1 . The average weekly price listed by the Commodity exchange of Bologna from initial stock exchange listing (usually the first week of July) to the commodity exchange listing of the last week of March of the following year after the harvest.

2. $15 € /$ ton deduction from $\left(p_{m g N}\right)$ as storage fee $\left(S_{15}\right)$ : $p_{m g N}=p_{m g}-S_{15}=325(€ / t)$

2. Transport costs are partially refunded to associated farms basing on the crop variety and the distance from the storage center.

3. Storage costs are totally beard by the contracting company.

Price can be increased through a social bonus, according to:

- product quality;

- capacity of the supply chain to enhance the products;

- economic performance of the contracting company, only for the associated farms.

5. Define the average price $\left(\underline{p}_{\underline{P}}\right)$ : for each period $P_{j}$, with:

$\underline{p}_{P_{j}}=\frac{\sum_{i=1}^{n} \underline{p}_{P_{j}}}{n}$

6. Define the net average price $\left(\underline{p}_{P N j}\right)$, deducting transport cost $\left(t_{12}\right)$ equal to $12 € / \mathrm{t}$

$\underline{p}_{\underline{P} N j}=\underline{p}_{\underline{P} j}-t_{12}$

7.1 If net average price is lower than guaranteed minimum price, we have:

$\underline{p}_{\underline{P} N j}<p_{m g} \rightarrow P_{j}=p_{m g N}=325$

7.2 If net average price is higher than guaranteed

minimum price, we have:
$\underline{p}_{P N_{j}}<p_{m g} \rightarrow P_{j}=p_{m g}+\frac{\left(\underline{p}_{P N_{j}}-p_{m g}\right)}{2}-s_{15}$

\section{Concluding remarks}

In the framework of the European Green Deal, the 'Farm to Fork' strategy (European Commission, 2020a) emphasises the importance of promoting a profound transformation of food systems to achieve environmental, social and economic sustainability goals, devoting/paying special attention to organic production in Europe, also to meet the growing demand of consumers increasingly attentive to the protection of health and the environment (Viganò et al., 2015; IFOAM \& FiBL, 2020; Zucconi, 2021). However, the economic sustainability of food systems is closely linked to the guarantee of fair prices and adequate profitability margins for the various players in the food chain. This is especially true for agricultural enterprises which, due to the combined effect of exogenous and endogenous factors, are exposed to increasing biological and market risk. In addition to the reduction in yields, due to a series of phenomena linked also to climate change, agricultural markets are characterised by strong instability and asymmetric price transmission along the value chain, which mainly penalises the actors upstream of the food chain. 
Despite the limited number of cases examined, the analyses carried out for the durum wheat sector have shown that the adhesion to innovative contractual tools, such as supply chain contracts, can be an effective solution to mitigate these problems. The mechanisms introduced for the establishment of 'fair prices' and the definition of a series of ancillary services (such as pre-financing or the guarantee of product purchase) make it possible to rebalance the bargaining power of agricultural companies towards the upstream and downstream sectors, obtaining adequate profitability margins. This also decreases market risk in years when, if there were an oversupply, farmers would not even be able to sell their product or would be forced to do so at unprofitable, below-market prices.

More generally, the organization of the supply chain by associations/cooperatives of farmers allows total control of production, starting from the selection of the seed, up to the phases with greater added value (industrial processing of semolina into pasta and distribution of final products) (Bailey et al., 2021). Supply chain contracts also offer a series of advantages at the level of territorial systems. Efficient and sustainable supply chains are essential, in fact, to obtain an improvement in logistics and, therefore, in the connection between the production system and the final demand for organic products. In this regard, a particularly interesting example is that related to public procurement, for the building of sustainable public canteens (school and hospital), which is often hindered by the absence of an adequate organizational level of agri-food companies.

For a more accurate assessment of supply chain contracts as a form of bottom-up innovation able to ensure economic sustainability for the different enterprises involved in the farm-to-fork activities, it is now necessary to extend the analysis expanding the number of cases examined (despite the difficulties in collecting information, linked to the sensitivity of the data), and considering other agri-food products and other regions/countries, also to overcome the limitations of the work. The evaluation of the organizational structure, with particular attention to the form of vertical and horizontal integration and the presence of supply chain contracts, is also an element of particular relevance to assess competitiveness on national and international markets and to develop policies for product enhancement. Such policies that are particularly urgent due to changes in the scenario, also triggered by the COVID 19 pandemic.

\section{Supplementary material}

Supplementary material can be found online at https://doi.org/10.22434/IFAMR2021.0103

Appendix 1. Interview scheme for stakeholders supply chain contracts.

Appendix 2. Interview scheme for presidents of agricultural consortium and cooperative.

\section{Acknowledgements}

Financial support from Innovative $\mathrm{PhD}$ 'Models for the diffusion and impact assessment of innovations for organic food chains', Department of Economics, Society, Politics, University of Urbino Carlo Bo.

\section{Conflict of interest}

The authors declare no conflict of interest.

\section{References}

Antonelli, G. and E. Viganò. 2018. Global challenges in traditional food production and consumption. In: A. Cavicchi and C. Santini (eds.) Case studies in the traditional food sector. A volume in the consumer science and strategic marketing series. Elsevier, Amsterdam, the Netherlands, pp. 25-46.

Bailey, A.R., F. Jia, H. Dong and T. Martins. 2021. Sustaining supply chain relationships for co-operatives success: the case of South Devon Organic Producers Co-operatives (UK). International Food and Agribusiness Management Review 24(1): 162-178. https://doi.org/10.22434/IFAMR2020.0062 
Bàrberi, P. 2015. Functional biodiversity in organic systems: the way forward? Sustainable Agriculture Research 4(3): 26-31. https://doi.org/10.5539/sar.v4n3p26

Baxter, P. and S. Jack. 2008. Qualitative case study methodology: study design and implementation for Novice researchers. The Qualitative Report 13(4): 544-559.

Blasi, G., A. Caruso and E. Viganò. 2016. Participatory design of a sustainable school canteen through the development of a Business Model Canvas. Economia Agro-Alimentare 18(3): 319-344.

Bobenrieth, E., B. Wright and D. Zeng. 2013. Stocks-to-use ratios and prices as indicators of vulnerability to spikes in global cereal markets. Agricultural Economics 44: 43-52.

Brümmer, B., O. Korn, K. Schlüßler and T. Jamali Jaghdani. 2015 Volatility in oilseeds and vegetable oils markets: drivers and spillovers. Journal of Agricultural Economics 67: 685-705.

Cacchiarelli, L. and A. Sorrentino. 2018. Market power in food supply chain: evidence from Italian pasta chain. British Food Journal 120: 2129-2141.

Carillo, F. 2016. Vertical integration in Italian pasta supply chain: a farm level analysis. Rivista di Economia Agraria 1: 47-66. https://doi.org/10.13128/REA-18377

Carillo, F., F. Caracciolo and L. Cembalo. 2017. Do durum wheat producers benefit of vertical coordination? Agricultural and Food Economics 5: 19. https://doi.org/10.1186/s40100-017-0088-7

Consiglio per la ricerca in agricoltura e l'analisi dell'economia agraria (CREA). 2020. Annuario dell'agricoltura italiana 2019. Available at: https://www.crea.gov.it/web/politiche-e-bioeconomia/-/annuario-dellagricoltura-italiana

De Olde, E.M., F.W. Oudshoorn, C.A. Sørensen, E.A. Bokkers and I.J. De Boer. 2016. Assessing sustainability at farm-level: Lessons learned from a comparison of tools in practice. Ecological Indicators 66: 391-404.

European Commission. 2009. Analysis of price transmission along the food supply chain in the EU. EC, Brussels, Belgium. Available at: https://ec.europa.eu/economy_finance/publications/pages/ publication16067_en.pdf

European Commission. 2020a. Communication from the Commission to the European Parliament, the Council, the European Economic and Social Committee and the Committee of the Regions. 2020. A Farm to Fork Strategy for a fair, healthy and environmentally-friendly food system. EC, Brussels, Belgium. Available at: https://eur-lex.europa.eu/legal-content/EN/TXT/?uri=CELEX\%3A52020DC0381

European Commission. 2020b. Communication from the Commission to the European Parliament, the Council, the European Economic and Social Committee and the Committee of the Regions. EU Biodiversity Strategy for 2030. Bringing nature back into our lives. EC, Brussels, Belgium. Available at: https:// eur-lex.europa.eu/legal-content/EN/TXT/?uri=CELEX:52020DC0380

European Commission. 2020c. Towards a sustainable food system: moving from food as a community to food as more of a common good. EC, Brussel, Belgium. Available at: https://ec.europa.eu/info/sites/info/files/ research_and_innovation/groups/sam/scientific_opinion_-_sustainable_food_system_march_2020.pdf

European Court of Auditors. 2020. Sustainable use of plant protection products: limited progress in measuring and reducing risks. ECA, Brussels, Belgium. Available at: https:/www.eca.europa.eu/en/Pages/ DocItem. aspx?did $=53001$

Filippi, M. and A. Chapdaniel. 2021. Sustainable demand-supply chain: an innovative approach for improving sustainability in agrifood chains. International Food and Agribusiness Management Review 24(2): 321-335. https://doi.org/10.22434/IFAMR2019.0195

Food and Agriculture Organisation (FAO). 2018. The future of food and agriculture - alternative pathways to 2050. FAO, Rome, Italy, $224 \mathrm{pp}$.

Gerini, O. 2021. I numeri chiave della filiera. In: Dalla rivoluzione verde alla rivoluzione bio - Il biologico tra presente e futuro. Presentation at SANA 2021. 9-10 September 2021. Bologna, Italy.

Götz, L., I. Djuric and T. Glauben. 2015. Wheat export restrictions in Kazakhstan, Russia and Ukraine: impact on prices along the wheat-to-bread supply chain. In: A. Schmitz and W.H. Meyers (eds.) Transition to agricultural market economies: the Future of Kazakhstan, Russia and Ukraine. CABI, Wallingford, UK.

Haile, M.G., M. Kalkuhl and J. Braun. 2014. Inter- and intraseasonal crop acreage response to international food prices and implications of volatility. Agricultural Economics 45: 693-710. 
IFOAM Organics International (IFOAM) and Research Institute of Organic Agriculture (FiBL). 2020. The world of organic agriculture - statistics \& emerging trends 2020. Available at: https://www.fibl.org/ fileadmin/documents/shop/5011-organic-world-2020.pdf

IFOAM Organics International (IFOAM). 2008. Definition of organic agriculture. IFOAM, Bonn, Germany. Available at: https://www.ifoam.bio/why-organic/organic-landmarks/definition-organic

Jang, J. and F. Olson. 2010. The role of product differentiation for contract choice in the agro-food sector. European Review of Agricultual Economics 37(2): 251-273. https://doi.org/10.1093/erae/jbq013

Jarzebowski, S., A. Bezat-Jarzębowska and B. Klepacki. 2013. Efficiency and integration in the food supply chain. International Journal on Food System Dynamics 4(3): 159-169.

Istituto di Servizi per il Mercato Agricolo Alimentare (ISMEA). 2020. Analisi della catena del valore della pasta biologica nella filiera italiana. ISMEA, Rome, Italy. Available at: https://www.ismeamercati. it/flex/cm/pages/ServeBLOB.php/L/IT/IDPagina/11493

Mariani, A. and E. Viganò. 2013. Il Commercio equo: un modello replicabile per lo sviluppo sostenibile. Rivista di Studi sulla Sostenibilità 1: 149-161. https://doi.org/10.3280/riss2013-001012

Marshall, M.N. 1996. The key informant technique. Family Practice 13: 92-97.

Miles, M.B. and A.M. Huberman. 1994. Qualitative data analysis: an expanded sourcebook. Sage Publications, Thousand Oaks, CA, USA.

Morales, L.E. 2017. The effects of international price volatility on farmer prices and marketing margins in cattle markets. International Food and Agribusiness Management Review 21: 335-349. https://doi. org/10.22004/ag.econ.269669

Mostafalou, S. and M. Abdollahi. 2017. Pesticides: an update of human exposure and toxicity. Archives of Toxicology 91(2): 549-599. https://doi.org/10.1007/s00204-016-1849-x

Ohashi, K. and T. Okimoto. 2016. Increasing trends in the excess comovement of commodity prices. Journal of Excess Commodity Prices 1: 48-64.

Ott, H. 2014. Volatility in cereal prices: intra-versus inter-annual volatility. Journal of Agricultural Economics 65(3): 557-578.

Patton, M.Q. 2001. Qualitative research \& evaluation methods. Sage Publications, Thousand Oaks, CA, USA.

Ricci, E.C., M. Peri and L. Baldi. 2019. The effects of agricultural price instability on vertical price transmission: a study of the wheat chain in Italy. Agriculture 9: 36.

Rodale Institute. 2015. The farming systems trial celebrating 30 years. Available at: https://rodaleinstitute. org/wp-content/uploads/fst-30-year-report.pdf

Rude, J. and H. An. 2015. Explaining grain and oilseed price volatility: the role of export restrictions. Food Policy 57: 83-92.

Santeramo, F.G. and E. Lamonaca. 2019. On the drivers of global grain price volatility: an empirical investigation. Agricultural Economics 65(1): 31-42. https://doi.org/10.17221/76/2018-AGRICECON

Science Advice for Policy by European Academies (SAPEA). 2020. A sustainable food system for the European Union. SAPEA, Berlin, Germany. https://doi.org/10.26356/sustainablefood

Sexton, R.J. and N. Lavoie. 2001. Food processing and distribution: an industrial organization approach. In: B.L. Gardner and G.C. Rausser (eds.) Handbook of agricultural economics. Vol. 1. Elsevier, Amsterdam, the Netherlands, 863-932.

Silverman, D. 2000. Doing qualitative research a practical handbook. Sage Publications, Thousand Oaks, CA, USA.

Skinner, C., A. Gattinger, M. Krauss, H.M. Krause, J. Mayer, H.M. Van der Heijden and P. Mäder. 2019. The impact of long-term organic farming on soil- derived greenhouse gas emissions. Scientific Reports 9: 1702. https://doi.org/10.1038/s41598-018-38207-w

Solazzo, R., G. Petriccione and M.A. Perito. 2015. Lo strumento contrattuale nella filiera del grano duro in Italia: i motivi della scarsa diffusione. Agriregionieuropa 11(43): 109-112.

Stake, R.E. 2013. Multiple case study analysis. Guilford Press, New York, NY, USA.

Sturla, A., E. Viganò and L. Viganò. 2019. The organic districts in Italy. An interpretative hypothesis in the light of the common pool resources theory. Economia Agroalimentare-Food Economy 21(2): 429-458.

Tadesse, G., B. Algieri, M. Kalkuhl and J. Von Braun. 2014. Drivers and triggers of international food price spikes and volatility. Food Policy 47: 117-128. 
Tamayo-Orbegozo, U., M. Vicente-Molina and O. Villarreal-Larrinaga. 2017. Eco-innovation strategic model. A multiple-case study from a highly eco-innovative European region. Journal of Cleaner Production 142(4): 1347-1367. https://doi.org/10.1016/j.jclepro.2016.11.174

Tremblay, M.A. 1955. The key informant technique: a nonetnographic application. American Anthropologist 59(4): 688-701.

Tuck, S.L., C. Winqvist, F. Mota, J. Ahnstrom, L.A. Turnbull and J. Bengtsson. 2014. Land-use intensity and the effects of organic farming on biodiversity: a hierarchical meta-analysis. Journal of Applied Ecology 51: 746-755. https://doi.org/10.1111/1365-2664.12219

Viganò, E. G. Antonelli, G.I. Bischi and F. Tramontana. 2015. Consumo e consumatori di prodotti alimentari nella società postmoderna. Economia Agro - Alimentare 17(1): 59-80. http://doi.org/10.3280/ ECAG2015-003002

Yin, R.K. 2018. Case study research and applications: design and methods. Sage Publications, Thousand Oaks, CA, USA.

Zanni, G. and D. Viaggi. 2012. I contratti di produzione per l'integrazione della filiera del grano duro in Italia. Agriregionieuropa 8(30). Available at: https://agriregionieuropa.univpm.it/it/content/article/31/30/icontratti-di-produzione-lintegrazione-della-filiera-del-grano-duro-italia

Zezza, A. 2016. L'esperienza dei Progetti integrati di filiera: esperienze nel settore cerealicolo. Agriregionieuropa 12(44). Available at: https://agriregionieuropa.univpm.it/it/content/article/31/44/lesperienza-deiprogetti-integrati-di-filiera-esperienze-nel-settore

Zucconi S. 2021. Le dimensioni del mercato interno e la proiezione sui mercati internazionali. In: Dalla rivoluzione verde alla rivoluzione bio - Il biologico tra presente e futuro. Presentation at SANA 2021. 9-10 September 2021. Bologna, Italy. 